\title{
Detailed Carbonate Stratigraphy of the Japan Sea Sediments During Last Glaciation-Holocene
}

\author{
Sergei A. Gorbarenko ${ }^{1}$, Svetlana G. Pliss ${ }^{1}$, John R. SOUthon ${ }^{2}$, Michael Kashgarian ${ }^{2}$, \\ NATAL'YA B. VERKHOVSKAYA ${ }^{3}$ and ALEXANDER S. KUNDYSHEV ${ }^{3}$
}

(Manuscript received 31 May 1994, in final form 16 December 1994)

\begin{abstract}
Cores J-3-RGA, J-11-RGA (south and central part of the Japan Sea) were studied for $\delta^{18} \mathrm{O}$, palynological analyses, determination of carbonate and organic carbon content in sediments and dating by AMS methods. New AMS data on the J-11 core helped to identify the age of A-Tn volcanic ash as 25 thousand years. The Synthesis of the obtained data and the data provided by other cores taken in the Japan Sea reveal the detailed carbonate stratigraphy of the Japan Sea sediments for the last $25 \mathrm{Ky}$ formed in the course of the paleoceonographic evolution of the basin. The carbonate horizons $(\mathrm{CH}) 1,2$, 3 , are the result of the last glaciation event; they are related to the sea level regression and the semireduction condition of the bottom. The $\mathrm{CH} 4$ and $\mathrm{CH}$ 5 horizons were formed during the transition period, and probably correlate with the cold events of Oldest and Younger Dryas. The CH 6 and $\mathrm{CH} 7$ were accumulated in Holocene sediments, and they are related to insufficient changes in the Japan Sea environment.
\end{abstract}

(Key words: Carbonate stratigraphy, Japan Sea, Sediment)

\section{INTRODUCTION}

The Paleoenvironment dynamics of the Japan Sea is a natural model of regional climatic changes in the past. To understand the development of the regional climatic system, scientists have been paying much attention to the study of the marine paleoenvironment (Oba et al., 1991, Gorbarenko, 1987). Of particular interest are the paleoceanographic changes of the basin in the past 25,000 years by virtue of the fact that this period of time covers different climatic epochs and the dynamics of the transitional process from the glacial condition to an interglacial one. The study of several cores covering a major part of the sea area have

1 Pacific Oceanological Institute, Baltiyskaya, 43, Vladivostok, 690041, Russia

2 Lawrence Livermore National Laboratory, Livermore, CA 94551-9900, U.S.A.

3 Biologiya-Soil Institute, Prospect 100-Vladivostok, 159, Vladivostok, 690022, Russia 
resulted in $\delta^{18} \mathrm{O}$ foraminifera records, carbonate and organic carbon and opal contents in the sediments. All these date have shown similar trends in the paleoenvironment development of the basin over the past 30,000 years. Hence, the characteristic feature of the paleoceanology of the basin is the desalination of surface waters by $5-6^{\circ} \%$ (and the decrease of $\delta^{18} \mathrm{O}$ planktonic formainifera by $2.5-3^{\circ} \%$ o ) during the maximum of the last glaciation (Oba et al. 1980, Gorbarenko 1983). Many scientists have noted the weakening of the vertical water circulation of the basin and the decrease in the $\mathrm{O}_{2}$ content in bottom waters. The sharp enhancement of the reducing processes in the surface layer of sediments resulted in the occurrence of reduced sulphur (bramboidal pyrite) and the improved preservation of carbonate shells. Given enough data, it should be possible to mark out two horizons enriched with calcium carbonate in sediments of the Japan Sea during the last glaciation in the Holocene. The low horizon approximately complies with the maximum of the last glaciation and the upper one fits the completion of the glaciation and changes to the Holocene (Gorbarenko, 1987).

The study of sediment cores from Cruise of $R / V$ "Akademik Aleksander Vinogradov" provided the possibility for a more comprehensive stratigraphic classification of the sediments of the Japan Sea at that time. This study also served as the basis for more detailed paleoceanologic reconstruction. Thus, the data from the J-3 RGA and J-11 RGA cores correlated with those obtained earlier and made it possible to distinguish of 3 carbonate horizons in the sediments of the last glaciation, 2 horizons of the transition period and 2 horizons of the Holocene. The different carbonate contents of the sediments characterize the changes in water productivity, bottom ventilation and chemical properties of bottom waters which had an influence on the preservation of carbonate shells at the bottom. Consequently, the datailed reconstruction of carbonate content changes in the sediments is one of the most important criterion in the study of the paleoenvironment of the basin. Radiocarbon dates obtained by the Accelerated Mass-spectrometry (AMS) method from core J-11 helped to solve the A-Tn layer age problem and to determine the age of some specified carbonate horizons.

\section{MATERIAL AND METHODS}

Core J-3 RGA is drawn in the south part of the Tsushima Basin from the depth of 1400 $\mathrm{m}\left(35^{\circ} 53.8^{\prime} \mathrm{N}, 130^{\circ} 14.9^{\prime} \mathrm{E}\right)$, while Core J-11 RGA is taken from the north slope of Yamato

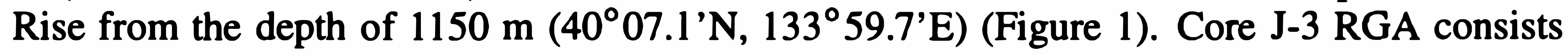
of homogeneous silty clay. A pumice layer previously attributed to the U-Oki eruption is observed on the horizon $489-441 \mathrm{~cm}$. The J-11 RGA core sediments consist of clayey silt at intervals $0-23$ and $84-131$ and silty clay at interval $23-84 \mathrm{~cm}$. There is the addition of volcanogenic material at the interval $144-146 \mathrm{~cm}$.

Carbonate and organic carbon contents in the sediments were determined by the coulonometric titration method using an AN-7529 analyzer. Total and carbonate carbons were released by roasting samples at $1100^{\circ} \mathrm{C}$ and dissolving diluted hydrochloric acid. The organic carbon content was calculated from the difference between total and carbonate carbon. The $\delta^{18} \mathrm{O}$ foraminiferal analyses of the $\mathrm{J}-11$ core was carried out on a three-collectors mass spectrometer VG using the conventional technique in Dr. Lloyd D. Keigwin's laboratory (Woods Hole Oceanographic Institute, USA). Planktonic foraminiferal shells Neogloboquadrina pachyderma sin for isotopic analysis were picked up from the sediment fraction 125$250 \mu \mathrm{m}$. Then they were dissolved in $100 \%$ orthophosphorous acid at a temperature of 


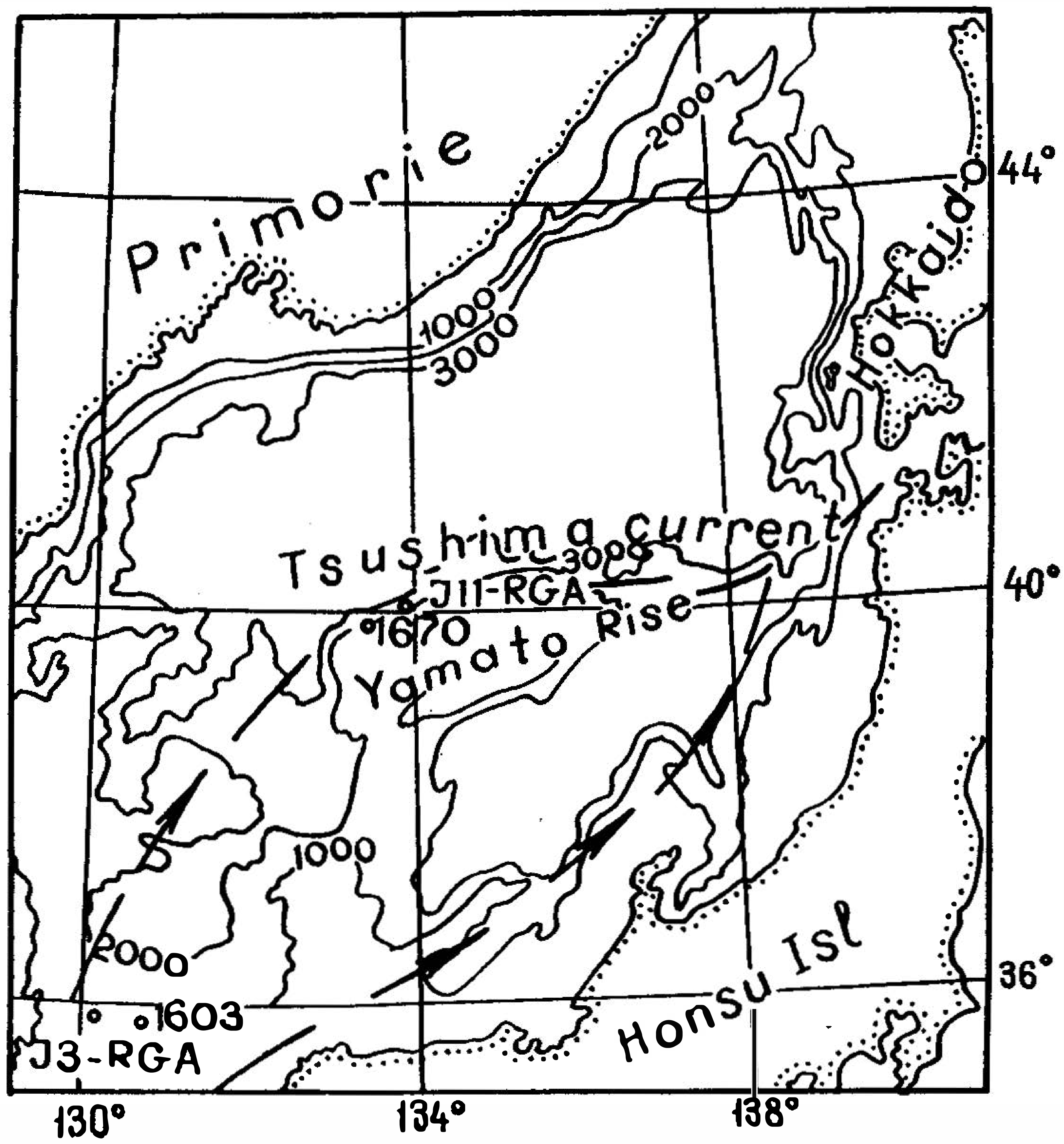

Fig. 1. Location of the studied Cores J-3,11-RGA and 1603, 1670, KH-79-3, C-3 in the Sea of Japan.

$70^{\circ} \mathrm{C}$ without preliminary processing. Oxygen and carbon isotopic data are presented in the permillage relative PDB standard (Appendix A).

Samples of sediments were processed by alkaline separation method with the subsequent acetolis, and washing as well as preparing temporary glass-slides. They were investigated mainly using the Amplival microscope at $\times 600$. At least two slides of each sample were scanned to reveal. all spore/pollen taxa. At least 300 microfossils for each sample were counted. The percentages of the three main groups (spores, arboreal and nonarboreal pollen) were calculated; the percentage of each taxon within a corresponding group is calculated too. If any of the groups was small, it was counted up to a hundred separately. After scanning, the microfossils were washed out with alcohol into a test-glass and preserve there.

\section{TIMING FRAME}

As the basis for the correlation of sediments, the isotope-oxygen curves of the planktonic foraminifera, AMS dates, position of the dated layers of volcanic ashes, general climatic tendencies obtained by the micropaleonotological method and the detailed variations in the carbonate content in sediments were used. The ages of the volcanogenic ashes Ah, U-Oki, A-Tn were considered to be estimated thousand years; 9.3 thousand years and 2122 thousand years respectively (Mashida and Arai, 1981). Tephra K-Ah, U-Oki and A-Tn are represented mainly by bubble walled shard (refractive index 1.508-1.514), pumiceous 
shard (1.514-1.124) and again bubble walled shard (1.498-1.501) respectively following procedures by Mashida and Arai (1981). The authors express a great gratitude to Dr. Igor V. Utkin (Pacific Oceanological Institute) for helping in the identification of the ash layers. The Volcanogenic layer A-Tn lies at the basis of the last glacial sediments. Because of its key stratigraphic position, its age was verified by the radiocarbon dates of the Nara Basin sediments (south-east part of Honsu Island). The A-Tn age equals 24 thousand or more years (Azuma et al., 1983). Based on paleogeographic data correlation and keeping in mind the climatic changes of the surrounding area and the paleoceanology of the Japan Sea, the age of A-Tn was considered to be 25 thousand years (Gorbarenko, 1987). Kato (1984) estimated the age of A-Tn ashes at 26 thousand years by radiocarbon dates of the core taken from the East China Sea.

The following peculiar characteristics of the $\delta^{18} \mathrm{O}$ curves of the Japan Sea planktonic foraminifera were used for sediment correlation: the decrease in the $\delta^{18} \mathrm{O}$ values above the A-Tn layer resulting from the last sea regression and freshening of surface waters; the minimal value of $\delta^{18} \mathrm{O}$ during the maximum of the last temperature fall and the lowest position of sea level; the increase in $\delta^{18} \mathrm{O}$ at the beginning of transgression during the late glaciation; and the $\delta^{18} \mathrm{O}$ decrease in the transition to the Holocene deposits (the boundary between the 1 -st and the 2-nd isotopic stages) (Gorbarenko, 1987). The Core J-11 RGA was studied for diatoms and radiolaria (Drs. I. B. Tsoy and V. V. Shchastina Pacific Oceanological Institute). Unfortunately only the upper $8 \mathrm{~cm}$ and $30 \mathrm{~cm}$ of the sediments in the core have a sufficient quantity of diatomic and radiolarian fossils to enable micropaleontological analyses. I. B. Tsoy and V. V. Shchastina conclude that the upper $30 \mathrm{~cm}$ of the sediment were accumulated during the Holocene period. To analyze the cores 1603 and J-11, Verkhovskaya et al., (1992) used palynological data also. The greatest content of the organic carbon in the sediments on the boundary between late the glaciation and Holocene is a good stratigraphic indicator of the sediments as well (Gorbarenko, 1987).

\section{DISCUSSION OF RESULTS}

Due to the different rate of sedimentation in the cores and different details in the sampling, not all carbonate peaks are pronounced in each core. Figures 2, 3 show a generalized scheme of the carbonate-content changes in sediments and the obtained data from Cores J-3 and J-11 which are compared to those of 1603 (Verkhovskaya et al., 1992) and KH-79-3, C-3 (Oba et al., 1991). For the correlation of the sediments and the subsequent paleoceanological reconstructions, the isotopic geochemical and micropaleontological data of other cores from the Japan Sea were taken into account (Gorbarenko 1987, 1993, Oba et al., 1991, Keigwin and Gorbarenko, 1992). Radiocarbon dates as stated by the AMS method for the shells of foraminifera Neogloboquadrina pachyderma sin., (Appendix B) measured in Core J-11 helped to determine the age of the volcanic layer A-Tn. It is evident that the age of A-Tn ash is greater than the one established ealier, i.e. 25 thousand years ago. This important fact suggests the associaton of paleoanographic changes in the Japan Sea with the temperature fall which occurred in the surrounding area about 25-23 thousand years ago (Yasuda, 1983, Ooi, 1992).

The spore/pollen spectra from 271-60 cm are characterized by the prevalence of herb pollen which is mostly Artemisia. Ephedra, Sparganium, Polygonum sect. Bistorta, P. sect. Aconogonon, Thalictrum Sanguisorba, Valeriana and families Ericaceae, Poaceae, Cyperaceae, Li liaceae, Ranunculaceae, Chenopodiaceae, Caryophyllaceae, 


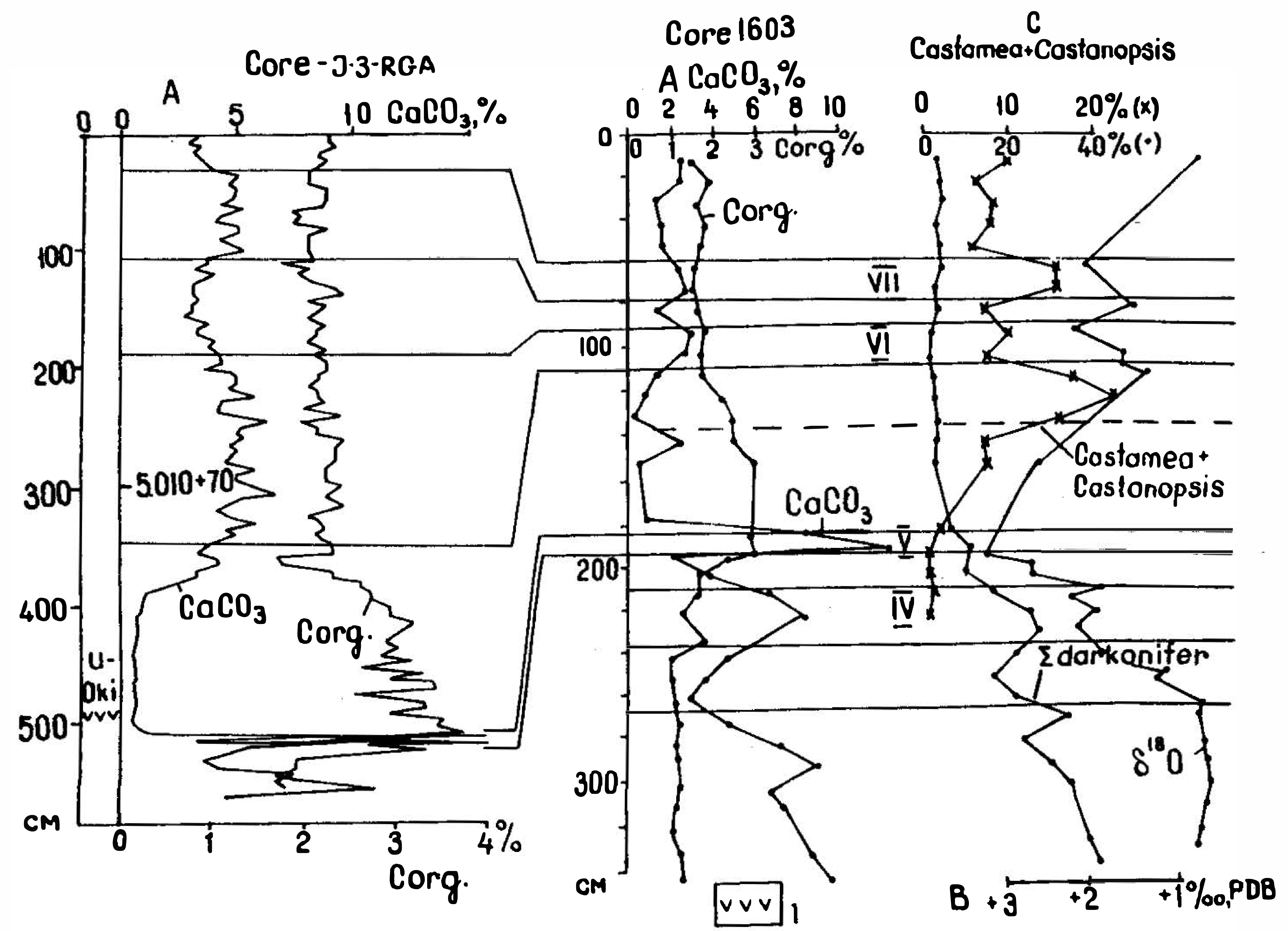

Fig. 2. Core J-3-RGA; A - Carbonate and organic contents in sediment (in \% per $\mathrm{lg}$ of dry bulk sediment). Core 1603; A - Carbonate and organic carbon content; $\mathrm{B}-\delta^{18} \mathrm{O}$ planktonic foraminifera Neogloboquadrina pachidenna sin, per mile to PDB standard; C- Content of wann pollen grains (Castamea plus Castanopsis) and cold (sum of dakrconifer) in \% accordingly (Verkhovskaya et al., 1992). On the left marginal AMS dates: 1-volcanic ash; I, II, III, IV, V, VI, VII - number of carbonate horizons CH-1, 2, 3, $4,5,6,7$, respectively.

Rosaceae, Lamiaceae, Fabaceae, Brassicaceae, Apiaceae, Dipsacaceae, Cannabaceae, Polemoniaceae, Cichoriaceae, and Asteraceae are presented by a minor number of pollen grains or by single ones. There is a predominance of dark conifer pollen (Picea, Abies, Tsuga), Pinus s.g. Haploxylon and Betula within the arboreal group. The pollen of broadleaved plants is rather varied and belongs to Ulmus, Quercus, Fagus, Castanea, Carpinus, Fraxinus, Juglans, Tilia, Corylus, Acer, Aralia. However, its distribution within the core is not uniform. The Pollen portion of Quercus from 232-169 cm makes up 7.3-10.3\%, and Ulmus 4,5-9,2\%. The number of thermophilous taxa reaches 8-10.

From 160 to $70 \mathrm{~cm}$ only single pollen grains of broad-leaved trees occur, and their composition becomes meager (the taxa numbers are reduced to 4-5). Spores belong to Polypodiaceae mainly and Bryalesand Lycopodium to a lesser extent. In core interval between 70 and $55 \mathrm{~cm}$ the spore/pollen spectra are changed significantly (Figure 3). Above $55 \mathrm{~cm}$, the pollen of trees and shrubs decreases rapidly. The Quercus pollen begins to play the main role, the variety of broad-leaved plants increases to 9-11 taxa. In the core top the pollen of conifers predominate again but at the expense of Pinus. It should be noted that both P. s.g. Haploxylon and P. s.g. Diploxylon are presented here in a rather 




Fig. 3. Core J-11-RGA; A - Carbonate and organic content in sediments; B - $\delta^{18} \mathrm{O}$ N. pachidenna sin.; C - Pollen content of dark conifers and Quercus in \%; A - Carbonate and organic content is sediment of core $\mathrm{KH}-79-3, \mathrm{C}-3$ (Oba et al., 1991); B- $\delta^{18} \mathrm{O}$ planktonic foraminifera; 2 - thin laminated sediments.

great quantity. The herb group is predominated by Artemisia as lower but the taxa variety decreases perceptibly.

According to the information of American, Japanese and Chinese researchers, dark conifer forests were replaced by broad-leaved ones during a transition phase between the Pleistocene and Holocene, which is about 12,000-10,000 years BP (Heusser and Morley, 1990; Tsukada, 1986; 1988; Sakaguchi, 1989; Sun et al., 1991). However this change took place at different latitudes non-simultaneously. The percentage of the Quercus pollen in the spectra increases rapidly in profiles of South Japan areas in the period of about 12,000-11,000 years BP. (Tsukada, 1986). A similar distribution of this pollen was described from the deep sea cores taken east off the Japan Archipelago. The maximum of Quercus pollen curve from the core KH79-3-C6 was dated to 10,700-9,700 years BP (Heusser and Morley, 1990) in contradistinction to the more northern areas where the oak forests expansion only began at this time interval.

The latitude of the Yamato Submarine Ridge within which the J-11 core has been taken is closer to the latitude of North Japan. However, the Yamato area was influenced by the Tsushima branch of the Kuroshio warm current. Probably, the changes of the spore/pollen spectra above $55 \mathrm{~cm}$ have reflected a sharply intensified inflow of the wann water of this current into the Japan Sea resulting from the transgression that began in the period of about $15,000-14,000$ years BP (Gohara, 1976). The authors believe the significant increase in pollen produced by the vegetation of the more southern territories is connected exactly to this event. Consequently, the Pleistocene/Holocene boundary in the core corresponds to the Quercus pollen maximum, which is located within the core interval from 39 to $25 \mathrm{~cm}$. 
Carbonate horizons $\mathrm{CH} \mathrm{1,2}$ and 3 were formed during the last glaciation. The Micropaleontologic data on the cores J-11 (with interval 160-60 cm), 1670, 1682 (Gorbarenko, 1987) show that sediments above the A-Tn with light values of $\delta^{18} \mathrm{O}$ were accumulated during the last glaciation. The regression of the sea level brought about the decreasing water exchange with the Pacific Ocean and a strengthening of the fresh water influence upon the water balance in the Japan Sea. During this period, the atmospheric precipitation and river runoff were greater than the evaporation. The Characteristic property of the given latitude at glaciation in particular caused the freshening of surface waters and the decreasing of $\delta^{18} \mathrm{O}$ of waters and planktonic foraminifera.

Carbonate horizon 1 ( $\mathrm{CH1}$ ) just over the A-Tn layer was formed at the beginning of the sea regression and corresponding lightening of $\delta^{18} \mathrm{O}$ In many cores of the Japan Sea, CH1, the maximum of which accounts for 22.5 thousand years, is represented by thin laminated sediments. Their accumulation is likely to correlate with weakening of the vertical circulation of waters and decrease in the oxygen-content in bottom waters. The deficit of $\mathrm{O}_{2}$ in bottom waters is also confinned by the inhibition of benthonic foraminiferal fauna in the deposits embracing carbonate peaks 1-3. In the above lying sediments, the $\mathrm{CH} 1$ thin stratified structure was replaced by a massive texture, while the $\mathrm{CaCO}_{3}$ content decreased. It is conceivable that at that time sea regression slowed down or even changed for minor transgression.

$\mathrm{CH} 2$ and $\mathrm{CH} 3$ accumulation took place with the further drop in sea level and the increasing isolation of the basin. The strongest freshening of the basin's surface waters (the lowest value of $\delta^{18} \mathrm{O}$ ) was observed in the second part of $\mathrm{CH} 2$ and in $\mathrm{CH} 3$. Possibly, these deposits correlate with the late glaciation and the lowest level of the sea. The CH-2 and $\mathrm{CH}-3$ in the Core J-11 are separated by a minor thickness of sediments with the lower carbonate content. Unfortunately, the rare sampling for palynological analysis does not permit the correlation of carbonate variations with climatic changes in this core. The possibility that this interval of minor carbonate deposits resulted from insufficient rise in temperature and changes in the sea level cannot be excluded. Sediments of $\mathrm{CH}-2$ in the of Core J-11 and in the Core $\mathrm{KH}-79-3 \mathrm{CH} 2$ and $\mathrm{CH} 3$ also have thin laminated texture compatible accumulation of deposits at weak aeration of bottom waters.

The CH-4 and CH-5 fall at the completion of the late glaciation period and at the beginning of the transgression of the sea. The inflow of the Pacific waters into the Japan Sea increased and the salinity of surface waters also gradually grew as is obvious from the production of heavy $\delta^{18} \mathrm{O}$. According to 1603 core records, an increase was noticed in the carbonate content of the sediments correlated with the slight fall in temperature on sporepollen evidence and the inhibition in $\delta^{18} \mathrm{O}$ increase. This is why it is believed that $\mathrm{CH}-4$ formation fell with the Oldest Dryas decrease in temperature of the transition period (14-13 thousand years ago) (Berger, 1990).

CH-5 is situated immediately under the volcanogenic layer U-Oki (9300 years ago,) and according to AMS dating it can be dated at 11,150 years ago. On diatom and polynological analyses of the core 1603 (Verkhovskaya et al., 1992) the fall in the temperature of surface waters and the inhibition of the rise in atmospheric temperature were also observed during $\mathrm{CH}-5$ accumulation. It is likely that the time of $\mathrm{CH}-5$ accumulation is synchronous with the short-time fall in temperature (Younger Dryas) and attendant decrease in aeration of bottom waters and better preservation of shell foraminiferas in the sediment. At this time, the sea level reached mark minus 65 meters (Fairbanks, 1989), and the water exchange with the Pacific Ocean had increased significantly while the salinity of the surface waters had been normalized ( $\delta^{18} \mathrm{O}$ equal to $+3 \sim+3.5^{\circ} / o$ o). 
The next time lapse up to the volcanic layer K-Ah (6300 years ago) was characterized by the rise in temperature of surface waters and the atmosphere. By 6 thousand years, the sea level was $-10 \sim-15 \mathrm{~m}$, and the $\delta^{18} \mathrm{O}$ value decreased up to $+1^{o} / o o$. This value is typical of the isotope-oxygen background of the World Ocean in the interglacial period. Usually, the carbonate content in Holocene deposits was lower than that in glacial and transition sediments owing to the intensive vertical circulation of waters. The strong aeration of bottom waters at the increased productivity of surface waters resulted in an intensive release of $\mathrm{CO}_{2}$ and a high corrosion of carbonate shells in the surface layer of sediments. The traces of the solution of planktonic foraminiferal shells were seen under microscope. The strongest solution of carbonate shells, and the lowest $\mathrm{CaCO}_{3}$ content are characteristic of sediments accumulated from 9 to 6.5 thousand years ago. At this time and at CH5 (10-11 thousand years ago), the deposits of the Japan Sea in all analyzed cores had the highest organic carbon content (up to $3-4 \%$ per dry weight of sediment). It is possible that the productivity of the Japan Sea at that time was maximal. Oceanographic parameters, similar to those of the present time, were set in the Japan Sea some 7 thousand years ago. Two less pronounced carbonate content rises (CH6, CH7) were noted in Holocene deposits. The last of them, $\mathrm{CH}-7$, correlates well with the time if insufficient temperature rise in surface waters and atmosphere established by the micropaleontological method in the Core 1603 (Verkhovskaya et al., 1992). The CH-6 lying slightly above the volcanogenic layer K-Ah was formed from the data of the Core 1603 at the end of the early Holocene rise in temperature, approximately 5,000 years ago, according to AMS dating. It is still elusive if the changes in planktonic foraminifera productivity or their preservation in bottom sediments are the reasons for the formation of $\mathrm{CH}-6$ and $\mathrm{CH}-7$ in the Japan Sea.

\section{CONCLUSION}

Using radiocarbon dates of planktonic foraminiferal shells, $N$. pachyderma, it was determined that the age of the widely spread A-Tn volcanic layer in the region was equal to 25 thousand years. Using a detailed complex analysis of several cores of the Japan Sea sediments corresponding to the period of the late glaciation, the transition period and Holocene, the authors established seven horizons with the increased calcium carbonate content $(\mathrm{CH})$ and made an attempt to determine their paleoceanologic causes. The formation of $\mathrm{CH} 1, \mathrm{CH} 2$ and $\mathrm{CH} 3$ in sediments during the late glaciation is related to sea level regression, moderation of ventilation of bottom waters and the improvement in the preservation of planktonic foraminiferal shells. The $\mathrm{CH} 4$ and $\mathrm{CH} 5$ of the transient period is probably correlated with cold events (Oldest Dryas and Younger Dryas). In the Holocene deposits, the carbonate content is low and those $\mathrm{CH} 6$ and $\mathrm{CH} 7$ rises formed after 6 thousand years are connected with insufficient changes in surface water temperature and paleoceanology.

Acknowledgments The Cores J-3-RGA and J-11-RGA taken on the 23-rd Cruise KEEPMASS on board the $R / V$ "Akademik Alexandr Vinogradov" formed the basis for this study. The authors would like to thank the leaders of the expedition, Drs. Min-Pen Chen and Alexander Bychkov, for the well arranged expeditional works. The authors also personally express their deep appreciation to Dr. Lloyd Keigwin for providing the possibility to do the $\delta^{18} \mathrm{O}$ and $\delta^{13} \mathrm{C}$ analyses from the Core $\mathrm{J}-11$ at his laboratory and to Mr. E. Franks for making the measurements. The authors express their greatest thanks to Drs. Irina Tsoy and Valentina Shchastina for the diatiom and radiolarian analyses of the Core J-11-RGA. They 
regret that due to the absence of representatives of the diatoms and radiolaria complexes in the late Pleistocene deposits of this core, they failed to do a full micropaleonological analysis.

\section{REFERENCES}

Azuma, U., H. Okuda, S. Yoshikawa, H. Hara, and M. Shimakura,1983: The Upper Pleistocene and Holocene of Sakate, Tawaramotocho Kashihara Archaeological Institute (ed) Report on the Excavation of the Sakate Site. Outline reports on archaeoogical site research during fiscal 1982 in the Nara Basin, Kashinara Archaeological Institute, 1, 175-182 (in Japanese).

Berger, W. H., 1990: The Younger Dryas cold spell -a quest for causes. Palaeogeogr. Palaeoclimato. Palaeoecol., 89, 219-237.

Fairbanks, R. G., 1989: A 17,000-year glacio-eustatic sea level record; the influence of glacial melting rates on the Younger Dryas event and deep-ocean circulation. Nature, 342, 637-642.

Gohara, V. V., 1976: Climatic fluctuations and sea level changes during the Late Pleistocene and Early Holocene. Pacific Geology., 11, 87-98.

Gorbarenko, S. A., 1983: Paleogeographic conditions in the central part of the Sea of Japan during the Holocene and Late Pleistocene from data on ${ }^{18} \mathrm{O} /{ }^{16} \mathrm{O}$ in foraminifera tests. Okeanologiya, 23, 300-303 (in Russian).

Gorbarenko, S. A., 1987: The Paleogeography of the Japan Sea in the Upper Pleistocene and Holocene. Izvestia Akademii Nayk, Geogr. ser., 6, 106-113 (in Russian).

Gorbarenko, S. A., 1993: The reasons for surface water mass of the Sea of Japan freshening during the latest Glaciation revealed by oxygen isotopes. Okeanologiya, 33, 422-428 (in Russian).

Heusser, L. E., and J. J. Morley, 1990: Climatic change at the end of the Last Glaciation in Japan inferred from pollen in three cores from the Northwest Pacific Ocean. Quat. Res., 34, 101-110.

Kato, M., 1984: The Japan Sea since the last glacial age; Sediments mainly based on analysis of Core KH-79-3, c-3. Chikyu (Monthly, the Earth), 6, 529-537 (in Japanese).

Keigwin, L. D., and S. A. Gorbarenko, 1992: Sea level, Surface salinity of the Japan Sea and the Younger Dryas event in the northwestern Pacific Ocean. Quat. Res., 37, 346-360.

Machida, H., and F. Arai, 1983: Extensive ash falls in and around the Sea of Japan from large quaternary enuptions. J. Volcanol. Geotherm. Res., 18, 151-164.

Oba, T., Y. Haribe, and H. Kitazata, 1980: Analysis of the paleoenvironment since the last glacial age based on two cores from the Japan Sea. Archeology Nat. Sci., 13-49 (In Japanese with English abstract).

Oba, T., M. Katan, H. Kitazato, I. Koizumi, A. Omura, T. Sakai, and T. Takayama, 1991: Paleo-environmental changes in the Japan Sea during the last 85,000 years. Paleoceanography, 6, 499-518.

Ooi, N., 1992: Pollen Spectra around 20,000 years ago during the last Glacial from the Nara Basin, Japan. Quat. Res., Japan, 31, 203-212. 
Sakaguchi, Y., 1989: Some pollen records from Hokkaido and Sakhalin. Bull. Dept. Gerg. Oniv. Tokyo, 21, 1-17.

Sun, X. J., S. M. Yuan, J. L. Liu, and L. Y. Tang, 1991: The vegetation history of mixed Korean pine and deciduous forests in the Chang Bay Mt. Area, Jilt province, Northeast China during the last 13000 Years. Chinese J. Bot., 3, 47-61.

Tsukada, M., 1986: Vegetation in prehistoric Japan; The Last 20,000 Years Windows on Japanese Studies. The University of Michigan, 11-56.

Tsukada, M., 1988: Japan's Vegetation History. Kluwer, Dorbrecht, 459-518.

Verkhovskaya, N. V., S. A. Gorbarenko, and M. V. Cherepanova, 1992: Paleoenvironmental changes in the south Japan Sea and surrounding area during the end of the PleistoceneHolocene. Tikhookeanskaya Geologiya, 12, 12-21.

Yasuda, Y., 1983: Climatic changes in the last 50,000 years in Japan, especially on the fluctuations of snow fall in the side of the Japan Sea, Res. Relat. UNESCO Man and Biosphere program. 1982-1983, S1, 18-21 (in Japanese).

\section{APPENDIX A}

Analytic results on $\delta^{18} \mathrm{O}$ planktonic foraminifera Neogloboquadrina pachyderma (sinistral) Japan Sea core J11-RGA.

$\delta^{18} \mathrm{O}$ units are \%o PDB. Values are given in form $\mathrm{X}+\mathrm{S}$, where $\mathrm{X}=$ mean, $\mathrm{S}=1$ sigma.

\begin{tabular}{|c|c|c|c|}
\hline Depth $(\mathrm{cm})$ & $\delta^{18} \mathrm{O}$ & Depth $(\mathrm{cm})$ & $\delta^{18} \mathrm{O}$ \\
\hline $30-31$ & $3.275+0.018$ & $76-77$ & $1.096+0.008$ \\
$33-34$ & $3.107+0.022$ & $79-80$ & $0.683+0.012$ \\
$36-37$ & $3.689+0.007$ & $81-82$ & $0.799+0.007$ \\
$38-40$ & $3.498+0.006$ & $84-85$ & $0.875+0.010$ \\
$40-42$ & $3.612+0.017$ & $86-87$ & $0.937+0.003$ \\
$43-44$ & $3.500+0.008$ & $89-90$ & $1.276+0.006$ \\
$46-47$ & $2.984+0.019$ & $91-92$ & $1.488+0.020$ \\
$49-50$ & $2.876+0.012$ & $93-94$ & $1.588+0.008$ \\
$52-53$ & $2.578+0.012$ & $97-98$ & $1.826+0.013$ \\
$54-55$ & $2.539+0.010$ & $99-100$ & $1.936+0.006$ \\
$56-57$ & $1.759+0.006$ & $101-102$ & $2.008+0.005$ \\
$59-60$ & $1.755+0.005$ & $103-104$ & $2.025+0.006$ \\
$59-60$ & $0.916+0.004$ & $105-106$ & $2.135+0.016$ \\
60 & $0.863+0.004$ & $107-108$ & $1.769+0.013$ \\
$62-63$ & $0.398+0.009$ & $109-110$ & $1.891+0.006$ \\
$64-65$ & $0.604+0.006$ & $111-112$ & $2.097+0.011$ \\
$66-67$ & $0.603+0.019$ & $115-116$ & $1.937+0.006$ \\
$66-67$ & $0.646+0.014$ & $119-120$ & $2.089+0.005$ \\
$68-69$ & $0.687+0.010$ & $121-122$ & $2.213+0.010$ \\
$70-71$ & $0.693+0.006$ & $123-124$ & $2.356+0.011$ \\
$73-74$ & $0.905+0.008$ & $125-126$ & $2.308+0.011$ \\
$75-76$ & $1.114+0.006$ & $127-128$ & $2.326+0.012$ \\
\hline
\end{tabular}




\section{APPENDIX B}

AMS radiocarbon results at J-3-RGA and J-11-RGA cores.

\begin{tabular}{|c|c|c|c|c|c|}
\hline Core & $\begin{array}{c}\text { Depth } \\
(\mathrm{cm})\end{array}$ & $\begin{array}{c}\text { Accession } \\
\text { number }\end{array}$ & $\begin{array}{c}\text { Species foram. } \\
\text { measured }\end{array}$ & $\begin{array}{c}\text { Age, yrs } \\
\text { measured }\end{array}$ & $\begin{array}{c}\text { Age, yrs } \\
\text { corrected }^{\text {a }}\end{array}$ \\
\hline J-3 RGA & $295-300$ & 10547 & $\begin{array}{c}\text { Neogloboquadrina- } \\
\text { pachyderma dextral }\end{array}$ & $5010 \pm 70$ & $4610 \pm 70$ \\
\hline J-11 RGA & $39-40$ & 10125 & N.pachyderma sinistral & $11650 \pm 90$ & $11150 \pm 90$ \\
\hline & $121-122$ & 10122 & & $22840 \pm 280$ & $22440 \pm 280$ \\
\hline & $146-147$ & 10546 & & $25210 \pm 550$ & $24810 \pm 550$ \\
\hline
\end{tabular}

a - Radiocarbon ages were corrected by $-400 y$ rs to account for surface Japan Sea reservoir effects. 
